\title{
Pengaruh Leverage dan Likuiditas Terhadap Kebijakan Deviden
}

\author{
${ }^{1}$ Galih Prasetyo, ${ }^{2}$ Al Alawiyah, ${ }^{3}$ Siti Fatimah \\ ${ }^{1,2,3}$ Fakultas Ekonomi dan Bisnis, Universitas Budi Luhur Jakarta \\ e-mail: ${ }^{1} 1932600065 @$ student.budiluhur.ac.id, ${ }^{2} 1932600222 @$ student.budiluhur.ac.id, ${ }^{3} 1932600289 @$ \\ student.budiluhur.ac.id

\begin{tabular}{ccc}
\hline Diterima & Direvisi & Disetujui \\
$19-09-2021$ & $29-09-2021$ & $03-10-2021$ \\
\hline
\end{tabular}

\begin{abstract}
Abstrak - Perusahaan dituntut untuk dapat mempertahankan bisnisnya, tumbuh, dan meningkatkan daya saing dengan tetap memperoleh keuntungan (sustainable competitive growth). Gabungan Pengusaha Makanan dan Minuman Indonesia (GAPMMI) menyatakan bahwa industri makanan dan minuman menjadi salah satu sektor yang tertekan di tahun 2020 terutama pada saat pandemic Covid-19. Penurunan terbesar disebabkan oleh menurunnya konsumsi rumah tangga. Konsumsi rumah tangga berkontribusi sebesar 57\% terhadap Produk Domestik Bruto (PDB). Sementara itu, industri makanan dan minuman hanya berkontribusi sebesar 23,8\% terhadap PDB pada tahun 2020. Konsumsi rumah tangga turun 5,02 persen ke 2,84 persen selama kuartal I, dengan 44 persen berasal dari kontribusi makanan dan minuman. Padahal pengeluaran per kapita masyarakat kita 50 persennya untuk pangan, konsumen dan channel penjualan juga mulai bergeser ke pembelian online. Penelitian ini bertujuan untuk menguji pengaruh leverage dan likuiditas terhadap kebijakan dividen. Penelitian ini menggunakan 15 perusahan makanan dan minuman yang tedaftar di Bursa Efek Indonesia dipilih dengan metode purposive random sampling periode tahun 2016 sampai dengan tahun 2020. Metode statistik yang digunakan untuk menguji hipotesis adalah SEM-PLS (Structural Equation Model - Partial Least Square). Hasil penelitian menunjukkan bahwa variabel leverage tidak berpengaruh signifikan terhadap kebijakan dividen sedangkan pada variabel likuditas terdapat pengaruh positif signifikan terhadap kebijakan dividen.
\end{abstract}

Kata Kunci: Leverage, Likuiditas, Kebijakan Dividen

\begin{abstract}
Companies are required to be able to maintain their business, grow, and improve competitiveness while still earning profits (sustainable competitive growth). The Indonesian Food and Beverage Entrepreneurs Association (GAPMMI) stated that the food and beverage industry was one of the sectors that was under pressure in 2020, especially during the Covid-19 pandemic. The largest decline was due to a decline in household consumption. Household consumption contributes $57 \%$ to Gross Domestic Product (GDP). Meanwhile, the food and beverage industry only contributed $23.8 \%$ to GDP in 2020. Household consumption fell 5.02 percent to 2.84 percent during the first quarter, with 44 percent coming from food and beverage contributions. Whereas 50 percent of our society's per capita spending on food, consumers and sales channels has also begun to shift to online purchases. This study aims to examine the effect of leverage and liquidity on dividend policy. This study uses 15 food and beverage companies listed on the Indonesia Stock Exchange selected by the purposive random sampling method for the period 2016 to 2020. The statistical method used to test the hypothesis is SEM-PLS (Structural Equation Model - Partial Least Square). The results showed that the leverage variable had no significant effect on dividend policy, while the liquidity variable had a significant positive effect on dividend policy.
\end{abstract}

Keywords: Leverage, Liquidity, Dividend Policy

\section{PENDAHULUAN}

Era globalisasi dan revolusi industi 4.0 yang ditandai otomatisasi dan penggunaan teknologi informasi telah merubah lanskap bisnis secara global. Pada tingkat lokal, perusahaan dihadapkan transformasi bisnis yang cepat dan persaingan bisnis yang sangat kompetitif. Setiap perusahaan dituntut untuk dapat mempertahankan bisnisnya, tumbuh, dan meningkatkan daya saing dengan tetap memperoleh keuntungan (sustainable competitive growth). Salah satu sumber pembiayaan internal untuk mendorong pertumbuhan perusahaan adalah laba ditahan (retained eaning) disamping melalui option dan penerbitan saham baru.

Dalam hal penggunaan laba perusahaan, manajemen dapat membagikan sebagian keuntungannya untuk dibagikan dalam bentuk dividen dan menahan sebagian lainnya untuk membiayai investasi dan mendorong perumbuhan perusahaan dalam bentuk laba ditahan (retained earning). Keputusan strategis mengenai seberapa besar laba perusahaan yang akan dibagikan kepada pemegang saham dalam 
bentuk dividen sering isebut sebagai kebijakan dividen (dividend policy). Dalam menginvestasikan dananya, investor berharap untuk memperoleh imbal hasil (return) dimasa yang akan datang. Return dimaksud dapat berupa dividen dividend yield) maupun selisih antara harga jual dan harga beli saham (capital gain) yang dimiliki oleh investor pada saat melakukan perdagangan di bursa (Bawamenewi \& Afriyeni, 2019).

Kebijakan dividen merupakan pedoman yang digunakan oleh perusahaan dalam membuat keputusan strategis terkait dengan pembayaran dividen secara rasional. Membayarkan dividen atau tidak kepada pemegang saham menjadi keputusan penting bagi seorang manajer keuangan selain keputusan investasi dan keputusan finansial lainnya. Dalam konteks agency theory, dasar dari kebijakan dividen (dividend policy) yakni tanggung jawab manajemen (agent) untuk menciptakan kesejahteraan bagi para pemegang saham (principal), meningkatkan nilai perusahaan dan menjaga kepercayaan pasar. Kebijakan deviden merupakan kebijakan strategis yang diambil oleh manajeman keuangan untuk menentukan besarnya proporsi laba yang dibagikan kepada para pemegang saham dalam bentuk dividen tunai, dividend smoothing yang dibagikan, dividen yang dikonversi dalam bentuk saham, pemecahan saham (stock split), dan penarikan kembali saham yang beredar (buyback). Semua alternatif kebijakan ini diambil untuk meningkatkan kemakmuran para pemegang saham (Simetris \& Darmawan, 2019).

Gabungan Pengusaha Makanan dan Minuman Indonesia (GAPMMI) menyatakan bahwa industri makanan dan minuman menjadi salah satu sektor yang tertekan di tahun 2020 terutama pada saat pandemic Covid-19. Penurunan terbesar disebabkan oleh menurunnya konsumsi rumah tangga. Konsumsi rumah tangga berkontribusi sebesar 57\% terhadap Produk Domestik Bruto (PDB). Sementara itu, industri makanan dan minuman hanya berkontribusi sebesar 23,8\% terhadap PDB pada tahun 2020. Konsumsi rumah tangga turun 5,02 persen ke 2,84 persen selama kuartal I, dengan 44 persen berasal dari kontribusi makanan dan minuman. Padahal pengeluaran per kapita masyarakat kita 50 persennya untuk pangan, konsumen dan channel penjualan juga mulai bergeser ke pembelian online. (Deviyana, 2020)

Kebijakan dividen yang baik akan memengaruhi keputusan investor untuk menanamkan modal pada perusahaan. Di karenakan kondisi ekonomi di tahun 2020 yang sangat terpukul karena adanya pandemi COVID-19. Salah satu emiten perusahaan makanan dan minuman yaitu PT Sentra Food Indonesia Tbk (FOOD) mengalami rugi bersih hampir Rp 5 miliar dalam periode sembilan bulan pada tahun 2020. Kerugian tersebut karena penjualan turun lebih dari 10 persen yaitu pada pendapatan dari penjualan daging olahan dan mentah yang menjadi sumber utama pendapatan perseroan. Kondisi ini berbanding terbalik jika dibandingkan laporan keuangan selama 9 bulan (3 kuartal) pada tahun 2019 yang membukukan laba bersih sebesar Rp830,57juta. Dengan hasil minor tersebut FOOD memutuskan untuk tidak membagikan dividen sebagai akibat dari rugi bersih tahun 2020 (Market Bisnis, 2020)

Dalam beberapa penelitian sebelumnya, likuiditas perusahaan merupakan salah satu faktor penting yang harus dipertimbangkan oleh manajemen sebelum mengambil keputusan untuk menetapkan besarnya dividen yang akan dibayarkan atau melakukan kebijaka dividen (dividend policy) dengan hasil yang bervariasi. (Bawamenewi \& Afriyeni, 2019; Bilqis, 2018; Cahyani \& Badjra, 2017; Ginting, 2018; Prawira Ismanwan Yudi, Moh. Dzulkiron AR, 2014; Sari \& Sudjarni, 2015; Sudiani \& Darmayanti, 2016).

Likuiditas mengindikasikan atau menunjukkan kemampuan perusahaan untuk memenuhi kewajiban yang telah jatuh tempo, baik kewajiban terhadap pihak di luar perusahaan maupun internal perusahaan. Perusahaanperusahaan yang memiliki likuiditas baik atau dapat melunasi hutang jangka pendeknya saat jatuh tempo menarik perhatian investor dan mendapatkan kepercayaan dari investor (Kasmir, 2008).

Leverage merupakan rasio yang digunakan untuk mengukur tingkat hutang terhadap modal yang ditanggung oleh perusahaan dibandingkan dengan asetnya. Biasanya penggunaan leverage disesuaikan dengan tujuan perusahaan. Berdasarkan hasil pengukuran leverage, perusahaan akan mencari tahu beberapa cara terkait dengan penggunaan modal dan modal pinjaman serta menentukan rasio kemampuan perusahaan untuk memenuhi kewajiban. Kemampuan perusahaan untuk memenuhi kewajiban total untuk mendanai pengelolaan modal dan aset dapat menjadi salah satu poin penting yang perlu dipertimbangkan untuk menarik investor.

Dalam beberapa penelitian, leverage dikaitkan dengan kebijakan dividen (dividend policy) dengan hasil yang bervariasi. (Bawamenewi \& Afriyeni, 2019; Cahyani \& Badjra, 2017; Ginting, 2018; Patiruhu \& Paais, 2020; Prawira Ismanwan Yudi, Moh. Dzulkiron AR, 2014; Sari \& Sudjarni, 2015; Simetris \& Darmawan, 2019; Tahu \& Susilo, 2017)

\section{Stakeholder Theory}

Teori Pemangku kepentingan (stakeholder theory) menyatakan bahwa perusahaan memiliki keterkaitan dengan beberapa pemangkukepentingan (stakeholder) yang harus dikelola baik internal maupun eksternal. Teori pemangku kepentingan diperlukan untuk mengelola organisasi dalam lingkungan yang sangat kompleks dan bergejolak karena memberikan cara yang praktis, efisien, efektif, dan etis. Teori pemangku kepentingan adalah tentang menciptakan nilai lebih. Ada model sempit yang berfokus pada sekelompok kecil pemangkukepen- 
tingan seperti pemegang saham atau pelanggan, sementara kelompok pemangkukepentingan relevan yang jauh lebih besar tercakup dalam model yang lebih luas seperti pemasok, masyarakat dan pemerintah (Ramachandran, 2020).

Manajemen pemangku kepentingan yang baik sangat penting bagi bisnis apa pun untuk memberikan perubahan yang bertahan lama. Konsep stakeholder pada dasarnya merupakan redefinisi dari tujuan organisasi. Dalam rencana pengelolaan pemangkukepentingan, kelompok yang berbeda perlu diakomodasi. Teori pemangkukepentingan pertama kali dikembangkan oleh Ansoff yang mendefinisikan tujuan perusahaan untuk memasukkan, antara lain, rekonsiliasi kepentingan yang bertentangan dari berbagai pemangkukepentingan.

$$
\text { Teori pemangku kepentingan }
$$

menggambarkan hubungan timbal balik di antara berbagai aktor yang terlibat dalambperusahaan dan menawarkan tujuan alternatif perusahaan. Manajemen pemangku kepentingan dimaksudkan untuk menciptakan metode untuk mengelola kelompok dan hubungan yang berbeda. Organisasi perlu lebih memahami pemangku kepentingan mereka dan bagaimana mengelola mereka secara strategis.

\section{Signalling Theory}

Menurut (Brigham dan Houtson ,2011) dalam (Kurniawan dan Mawardi, 2017) teori sinyal mengasumsikan bahwa manajer perusahaan (issuer) memiliki informasi yang lebih lebih lengkap mengenai kinerja perusahaan daripada investor. Dengan informasi yang tidak sempurna, investor tidak dapat membedakan antara apakah laporan keuangan perusahaan berkualitas tinggi ataukah laporan keuangan perusahaan berkualitas rendah. Oleh karena itu, perusahaan berkualitas tinggi memilih untuk menurunkan harga saham untuk menandakan nilai sebenarnya perusahaan. Kondisi kritis dari model ini adalah bahwa kualitas sebenarnya dari perusahaan terungkap sebelum perusahaan melakukan tindakan yang memicu penilaian baru setelah penerbitan laporan keuangan.

Dalam beberapa penelitian teori sinyal dapat disimpulkan sebagai teori yang dapat mempengaruhi kebijakan deviden, karena teori ini memberikan informasi mengenai struktur modal, likuiditas dan pemberian deviden oleh perusahaan melalui laporan keuangan untuk mengurangi asimetri informasi. Informasi yang diterima oleh investor terlebih dahulu diterjemahkan sebagai sinyal yang baik (good news) atau sinyal yang jelek (bad news). Teori sinyal perusahaan memiliki lebih banyak informasi tentang prospek pendapatan perusahaan di masa depan daripada pemegang saham itu sendiri. Berdasarkan logika teori ini jika direksi menyatakan dividen yang lebih tinggi dari yang diantisipasi oleh pasar, maka akan diartikan sebagai sinyal bahwa perspektif keuangan perusahaan akan jauh lebih baik (Ross, 1973) dalam (Handayani dan Rachadi, 2009).

Investor percaya bahwa manajemen perusahaan tidak akan meningkatkan dividen jika tren ini tidak dapat dipertahankan di masa depan, tren pertumbuhan akan dipertahankan hanya jika korporasi memiliki harapan yang akan makmur di masa depan. Sebagai hasil dari tanda waktu yang lebih baik ini, investor membeli banyak saham yang menyebabkan kenaikan harga saham saat ini. Jika manajemen perusahaan memotong dividen, ini akan dilihat sebagai sinyal buruk bagi korporasi, sebagai akibat dari harga saham saat ini akan turun, karena pemegang saham percaya bahwa masa-masa sulit akan datang. Jika manajemen korporasi percaya pada teori ini, maka mereka harus mencari pesan bahwa keputusan mereka tentang investor dividen dapat ditransmisikan (Prasetyanta, 2016).

\section{Kebijakan Dividen}

(Darmawan, 2018) dalam bukunya yang berjudul "Manajemen Keuangan: Memahami Kebijakan Dividen Teori dan Praktiknya di Indonesia" menyatakan bahwa dividen adalah pembagian laba kepada para pemilik saham sesuai dengan jumlah saham yang dimilikinya. Pembayaran dividen kepada investor ini akan mengurangi laba ditahan (retained earning) dan kas yang dapat diakses oleh perusahaan, namun memberika manfaat kepada investor untuk memastikan tujuan utama perusahaan yitu menciptakan kesejahteraan bagi pemegang saham. Beberapa perusahaan mungkin memiliki rencana reinvestasi laba. Hal ini memungkinkan investor untuk memanfaatkan keuntungan mereka dengan sengaja untuk membeli option, biasanya tanpa komisi. Kadang-kadang, mereka tidak perlu membayar biaya atas reinvestasi keuntungan ini, tetapi mereka sebagian besar harus membayar komisi.

Dengan cara ini, dapat dikatakan bahwa strategi laba adalah suatu pendekatan untuk memutuskan sebagian dari keseluruhan keuntungan yang akan disebarluaskan sebagai keuntungan kepada investor dan jumlah keuntungan bersih akan diinvestasikan kembali sebagai pendapatan yang ditahan untuk diinvestasikan kembali. Dalam tinjauan ini, strategi laba diperkirakan menggunakan dua penanda, yaitu:

\section{Dividend Payout Ratio}

Dividend Payout Ratio adalah proporsi atau perbandngan antara dividen yang dibayarkan dan keuntungan bersih yang diperoleh perusahaan. Semakin tinggi proporsi pembayaran keuntungan akan menguntungkan bagi investor, namun akan mempengaruhi kemampuan perusahaan untuk melakukan reinvestasi dari laba ditahan. Secara matematis, dividend payout ratio dapat diformulasikan sebagai berikut:

$$
D P R=\frac{\text { Dividend }}{\text { Laba Bersih }}
$$

Sumber: Samrotun, (2015) 


\section{Dividend Per Share}

Dividen per lembar saham (DPS) atau disebut juga dividen per saham (dividend per share - DPS) adalah ukuran keuntungan yang akan dibagikan kepada investor setelah diperbandingkan dan standar tertimbang dari penawaran standar luar biasa. Besarnya dividen per lembar saham dapat dicari dengan rumus:

$$
\text { DPS }=\frac{\text { Total Dividend yang Dibagikan }}{\text { Jumlah Lembar Saham Beredar }}
$$

Sumber: Samrotun (2015)

\section{Dividend Yield}

Dividend Yield adalah proporsi moneter yang digunakan untuk mengukur seberapa banyak return investasi dari investasi saham yang diberikan kepada investor. Investor dapat memperoleh dividend yield sebagai hasil inestasi (return) atas saham yang dimiliki. Investor menempatkan sumber daya keuanan (saham) ke dalam perusahaan yang sedang berkembang dan mengharapkan pengembalian sebagai keuntungan modal di samping perubahan harga saham dari waktu ke waktu. Investor mengharapkan pengembalian yang stabil sebagai keuntungan di samping penambahan modal jangka panjang. Proporsi hasil keuntungan sangat membantu bagi pendukung keuangan yang mapan. Dividen yield dapat diukur dengan menggunakan rumus sebagai berikut:

$$
\mathrm{DY}=\frac{\text { Dividen Per Lembar Saham }}{\text { Harga Perlembar Saham }}
$$

Sumber: Samrotun (2015)

\section{Leverage}

Leverage merupakan rasio yang digunakan untuk mengukur sejauh mana aktiva perusahaan dibiayai dengan utang (Kasmir, 2012). Artinya seberapa besar beban utang yang ditanggung perusahaan dibandingkan dengan aktivanya. Semakin tinggi rasio Leverage ini menunjukkan semakin besar penggunaan utang yang mengakibatkan semakin besar pula risiko keuangan yang dihadapi oleh perusahaan. Penggunaan utang ditujukan untuk membantu dalam pencapaian laba yang diharapkan perusahaan. Namun laba bersih yang diperoleh tersebut tidak serta merta diikuti dengan kemampuan perusahaan dalam membayar dividen, sebab kewajiban membayar utang lebih diutamakan dari pada membayar dividen (Widjaya \& Darmawan, 2018). Leverage mempengaruhi tingkat pengembalian investasi berupa pendapatan dividen. Perusahaan yang Leverage operasinya tinggi akan memberikan dividen yang rendah. Penggunaan utang yang tinggi akan menyebabkan penurunan dividen karena sebagian besar keuntungan dialokasikan untuk pelunasan utang. Peningkatan penggunaan utang menurunkan tingkat konflik antara manajer dengan pemilik sehingga pemilik tidak terlalu menuntut pembayaran dividen yang tinggi (Trisna \& Gayatri, 2019). Leverage dalam penelitian ini menggunakan dua indikator yaitu:

\section{Debt to Equity Ratio (DER)}

Debt to Equity Ratio (DER) merupakan rasio keuangan rasio yang digunakan untuk mengukur besarnya proporsi hutang terhadap modal. Rasio ini digunakan membandingkan antara jumlah dana yang disediakan oleh kreditor (hutang) dengan jumlah dana yang berasal dari pemilik perusahaan (ekuitas). dengan Rasio ini berfungsi untuk mengetahui berapa bagian dari modal yang dijadikan jaminan hutang. DER dapat dirumuskan sebagai berikut:

$$
\text { DER }=\frac{\text { Total Utang }}{\text { Total Ekuitas }}
$$

\section{Sumber: Herry (2018:169)}

\section{Debt to Asset Ratio (DAR)}

Debt to Asset Ratio (DAR) merupakan rasio yang digunakan untuk mengukur perbandingan antara total asset dengan total utang. Rasio ini untuk mengukur seberapa besar asset perusahaan dibiayai oleh hutang atau seberapa bear hutang perusahaan dibandingkan dengan total asset yang dimiliki oleh perusahaan. Rasio ini juga sering disebut dengan struktur modal perusahaan. Debt to Asset Ratio (DAR) dapat dirumuskan sebagai berikut:

Sumber: Herry (2018:161)

$$
\text { DAR }=\frac{\text { Total Utang }}{\text { Total Asset }}
$$

\section{Likuiditas}

Herry (2019) menyatakan bahwa likuiditas merupakan indicator yang mengindikasika kemampauan perushaaan dalam memenuhi kewajiban jangka pendeknay. Rasio likuiditas adalah rasio yang dapat digunakan untuk mengukur seberapa jauh tingkat kemampuan perusahaan dalam melunasi kewajiban jangka pendeknya yang akan segera jatuh tempo. Jika perusahaan memiliki kemampuan untuk melunasi kewajiban jangka pendeknya pada saat jatuh tempo maka perusahaan tersebut sebagai perusahaan yang likuid dan begitupun sebaliknya. Untuk dapat memenuhi kewajibang jangka pendeknya, perusahaan harus memiliki tingkat ketersediaan jumlah kas yang baik atau asset lancer lainnya yang juga dapat dengan segera dikonversi atau diubah menjadi kas. Dalam penelitian ini likuiditas diukur dengan menggunakan dua indikator yaitu:

\section{Current Ratio}

Current Ratio merupakan rasio yang digunakan untuk mengukur kemampuan perusahaan dalam memenuhi kewajiban jangka pendeknya yang segera jatuh tempo dengan menggunakan total asset lancar 
yang tersedia. Dengan kata lain current ratio dapat menggambarkan seberapa besar jumlah ketersediaan asset lancar yang dimiliki perusahaan dibandingkan dengan total kewajiban lancar. Current Ratio dapat dirumuskan sebagai berikut:

$\mathrm{CR}=\frac{\text { Asset Lancar }}{\text { Kewajiban Lancar }}$

Sumber: Herry (2018:161)

\section{Cash Ratio}

Cash ratio Cash ratio adalah rasio yang digunakan untuk mengukur seberapa besar uang kas atau setara kas yang tersedia untuk membayar hutang jangka pendek, sehingga ratio ini dapat menggambarkan kemampuan perusahaan dalam melunasi kewajiban lancarnya yang akan segera jatuh tempo. Cash Ratio dapat dirumuskan sebagai berikut:

$$
\mathrm{CAR}=\frac{\text { Kas dan setara kas }}{\text { Kewajiban Lancar }}
$$

Sumber: Herry (2018:156)

\section{Kerangka Penelitian}

Tujuan penelitia ini adalah untuk menguji pengaruh leverage dan likuiditas terhadap kebijakan dividen (dividend policy). Kerangka penelitian merupakan sintesa tentang hubungan antara variabel yang disusun dari berbagai teori yang telah dideskripsikan. Selanjutnya dianalisis secara kritis sehingga menghasilkan sintesa hubungan antar variabel penelitian. Menurut (Sugiyono, 2011) "kerangka penelitian merupakan sintesa tentang hubungan antar vaiabel yang disusun dari berbagai teori yang telah dideskripsikan. Kerangka penelitian menggambarkan model hubungan dan pengaruh satu variabel terhadap variabel lainnya yang digunakan dalam penelitian".

Leverage adalah tingkat kemampuan perusahaan untuk memenuhi semua kewajiban keuangan yang terdiri dari utang jangka pendek dan utang jangka panjang. Leverage menunjukkan hubungan antara jumlah pinjaman yang diberikan oleh pemilik perusahaan. Semakin besar rasio ini menunjukkan bahwa semakin besar struktur modal dari utang yang digunakan untuk mendanai ekuitas yang ada.

Menurut (Kasmir, 2012) "menyatakan bahwa rasio likuiditas menggambarkan kemampuan perusahaan untuk memenuhi kewajiban jangka pendeknya". Fungsi dari rasio likuiditas adalah untuk menunjuk-kan atau mengukur kemampuan perusahaan untuk memenuhi kewajiban yang jatuh tempo, baik kewajiban kepada pihak di luar perusahaan maupun pihak internal perusahaan. Rasio likuiditas atau sering disebut rasio modal kerja, yang merupakan rasio untuk mengukur seberapa likuid sebuah perusahaan. Karena dividen adalah arus kas keluar, semakin kuat posisi likuiditas perusahaan berarti, semakin besar kemampuan perusahaan untuk membayar dividen. Berdasarkan landasan teori yang telah diuraikan dan diringkas dari hasil penelitian sebelumnya, berikut ini model kerangka penelitian mengenai analisis pengeruh leverage dan likuiditas terhadap kebijakan dividen:

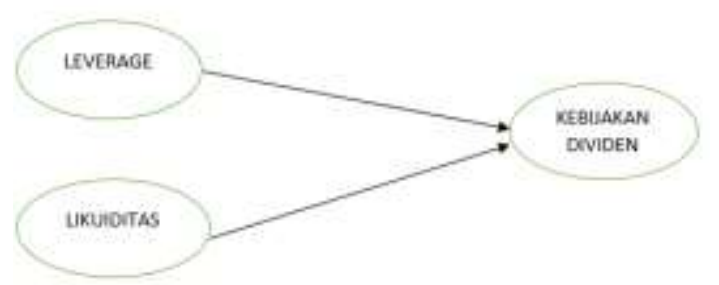

Sumber: Data dikelola Sendiri Gambar 1

Kerangka Konseptual Penelitian

\section{Hipotesis Penelitian}

Hipotesis merupakan jawaban sementara terhadap rumusan masalah penelitian, oleh karena itu ruusan masalah penelitian biasanya disusun dalam bentuk kalimat pertanyaan. Disebut sementara karena bersifat rasional atau logis sebagai hasil deduktif yang belum tentu benar (perlu diuji secara empiris).

\section{Pengaruh Leverage Terhadap Kebijakan Dividen}

Leverage adalah kemampuan perusahaan untuk memenuhi kewajiban (utang) baik jangka pendek maupun jangka panjang. Dalam beberapa penelitian sebelumnya, besarnya leverage akan mempengaruhi kebijakan dividen. Peningkatan hutang akan mempengaruhi tingkat pendapatan yang tersedia bagi pemegang saham, artinya semakin tinggi kewajiban suatu perusahaan, maka akan semakin besar kewajiban perusahaan, yang akan menyebabkan semakin kecilnya deviden yang dibagikan, karena laba yang diperoleh dialihkan untuk memenuhi kewajiban perusahaan. (Bawamenewi \& Afriyeni, 2019; Cahyani \& Badjra, 2017; Ginting, 2018; Kuswanta, 2016; Patiruhu \& Paais, 2020; Prawira Ismanwan Yudi, Moh. Dzulkiron AR, 2014; Sari \& Sudjarni, 2015; Simetris \& Darmawan, 2019; Tahu \& Susilo, 2017; Trisna \& Gayatri, 2019; Widjaya \& Darmawan, 2018; Zuhroh, 2019). Dalam penelitian ini, hipotesis yang diajukan dalam penelitian ini dapat disrumuskan sebagai berikut:

\section{$\mathrm{H}_{1}$ : Leverage berpengaruh terhadap kebijakan dividen}

\section{Pengaruh Likuiditas Terhadap Kebijakan Dividen}

Posisi likuiditas di perusahaan menjadi fakta yang mempengaruhi kebijakan dividen. Dividen tunai, misalnya, yang merupakan arus kas keluar untuk perusahaan. Oleh karena itu, jika perusahaan 
membayar dividen, itu berarti bahwa kas yang disediakan oleh perusahaan harus dalam jumlah besar dan akan mengurangi rasio likuid perusahaan karena uang tunai yang digunakan (Sutrisno, 2012). Biasanya, kondisi perusahaan yang rasio likuidnya tidak baik akan membagikan dividen dalam jumlah kecil, sedangkan jika perusahaan memiliki rasio likuid baik, maka dividen yang akan dibagikan juga besar.

H2 : Likuiditas berpengaruh terhadap kebijakan dividen

\section{METODE PENELITIAN}

Menurut (Sugiyono, 2017) "Metodologi penelitian adalah suatu teknik atau cara mencari, memperoleh, mengumpulkan atau mencatat data, baik berupa data primer maupun data sekunder yang digunakan untuk keperluan menyusun suatu karya ilmiah kemudian menganalisa faktor-faktor yang berhubungan dengan pokok- pokok permasalahn sehingga akan terdapat suatu kebenaran data-data yang akan diperoleh". Metode dalam penelitian ini menggunakan pendekatan kuantitatif. Menurut (Widiyanto, 2013) "Pendekatan kuantitatif adalah data yang diperoleh berupa angka-angka atau data kuantitatif yang diangkakan tersebut diolah, diinterpretasi dan ditarik kesimpulan dan diambil kesimpulan".

Penelitian ini memiliki dua variabel eksogen yaitu Leverage (X1) dan Likuiditas (X2). Variabel Leverage menggunakan indikator Debt to Equity Ratio (DER) dan Debt to Asset Ratio (DAR) sedangkan Likuiditas menggunkana indikator Current Ratio dan Cash Ratio. Dengan variabel endogen yaitu Kebijakan Dividen yang menggunakan indicator Dividend Payout Ratio, Dividend Per Share dan Dividend Yield. Dengan menggunanakan metode purposive random sampling serta terdapat 15 (lima belas) perusahaan makanan dan minuman yang terdaftar di Bursa Efek Indonesia pada tahun 2016 sampai dengan tahun 2020 yang telah memenuhi syarat penelitian.

SEM-PLS (Structural Equation Model Partial Least Square) digunakan untuk menganalisa data yang dihasilkan. Penggunaan SEM-PLS dikarenakan jumlah sampel dalam penelitian ini sedikit (kurang dari 100 sampel). SEM adalah model persamaan struktural dengan analisis multivariate yang memungkinkan untuk menguji hubungan antar variabel yang kompleks baik recursive maupun nonrecursive untuk memperoleh gambaran menyeluruh mengenai keseluruhan model. PLS adalah model persamaan struktural (SEM) yang berbasis komponen atau varian (variance) (Ghozali \& Latan, 2020).

Menurut (Ghozali \& Latan, 2020) "SEM PLS merupakan pendekatan alternatif yang bergeser dari pendekatan SEM berbasis kovarian menjadi berbasis varian. SEM yang berbasis kovarian umumnya menguji kausalitas/teori, sedangkan PLS lebih bersifat predictive model. Selain dapat digunakan untuk mengkorfimasi teori, PLS juga dapat digunakan untuk menjelaskan ada tidaknya hubungan antar variabel laten. PLS dapat sekaligus menganalisis konstruk yang dibentuk dengan indikator reflektif dan formatif. Hal ini tidak dapat dilakukan oleh SEM yang berbasis kovarian karena akan menjadi unidentified model".

\section{HASIL DAN PEMBAHASAN}

Penelitian ini menggunakan 15 sample perusahaan dari 30 perusahaan makanan dan minuman yang terdaftar di Bursa Efek Indonesia periode 2016-2020. Penelitian ini ditujukan untuk menguji pengaruh leverage dan likuiditas terhadap kebijakan dividen pada perusahaan makanan dan minuman. Dimana hasil pengujian dengan algoritma PLS dapat dilihat pada gambar di bawah ini:

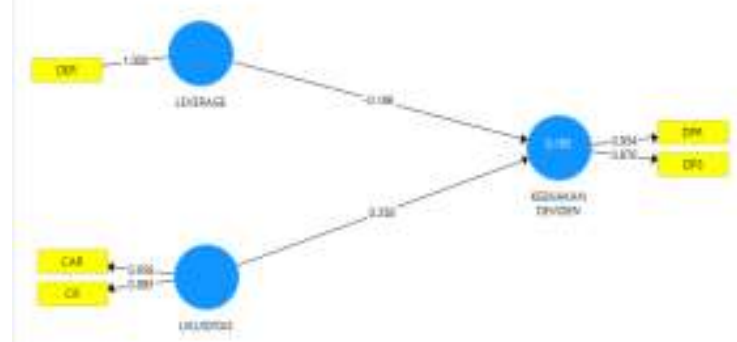

Sumber: Hasil SmartPLS

Gambar 2. Algoritma PLS

Tabel 1: Hasil Pengujian Hipotesis

\begin{tabular}{|c|c|c|c|c|c|}
\hline Variabel & $\begin{array}{l}\text { Original } \\
\text { Sample }\end{array}$ & $\begin{array}{l}\text { Std } \\
\text { Dev }\end{array}$ & $\begin{array}{c}\mathbf{T} \\
\text { Statistic } \\
>1.96\end{array}$ & $\begin{array}{c}P \\
\text { Values } \\
<0.05\end{array}$ & Ket \\
\hline $\begin{array}{l}\text { Leverage } \\
\rightarrow \text { Kebijak } \\
\text { an } \\
\text { Deviden }\end{array}$ & $-0,186$ & 0,104 & 1,795 & 0,073 & $\begin{array}{l}\text { Negati } \\
\text { f } \\
\text { Tidak } \\
\text { Sig }\end{array}$ \\
\hline $\begin{array}{l}\text { Likuiditas } \\
\overrightarrow{\text { Kebijakan }} \\
\text { Deviden }\end{array}$ & 0,358 & 0,130 & 2,745 & 0,006 & $\begin{array}{l}\text { Positif } \\
\text { Sig }\end{array}$ \\
\hline
\end{tabular}

Sumber: Hasil SmartPLS

Menurut (Ghozali \& Latan, 2020) "bahwa hasil korelasi antar konstruk diukur dengan melihat path coefficients dan tingkat signifikansinya. Suatu hipotesis dapat diterima atau ditolak secara statistik dapat dihitung melalui tingkat signifikansinya. Biasanya tingkat signifikansi ditentukan sebanyak $10 \%, 5 \%$ dan $1 \%$. Tingkat signifikansi yang dipakai dalam penelitian ini adalah sebesar 5\% dan dapat dilihat dari nilai $\mathrm{T}$ Statistic $>1.96$. Apabila tingkat signifikansi yang dipilih sebesar 5\% maka tingkat kepercayaan 0,05 untuk menolak suatu hipotesis".

Berdasarkan tabel diatas bahwa Leverage memiliki nilai $T$ Statistic sebesar 1,795 < 1.96 dengan nilai koefisien sebesar -0.186 berarti Leverege tidak 
berpengaruh terhadap kebijakan deviden dan tidak signifikan pada 0.05 yang berarti tinggi rendahnya nilai leverage perusahaan tidak mempengaruhi manajemen dalam membagikan deviden kepada investor.

Semakin tinggi rasio leverage menunjukkan semakin besar komposisi utang dalam struktur modal perusahaan yang mengakibatkan semakin besar pula risiko keuangan yang dihadapi oleh perusahaanyang bersangkutan. Penggunaan utang yang terlalu tinggi akan berpengaruh pada struktur modal perusahaan dan berpengaruh terhadap biaya bunga (debt cost) yang berdampak pada laba bersih perusahan. Namun laba bersih yang diperoleh tersebut tidak serta merta diikuti dengan kemampuan perusahaan dalam membayar dividen, sebab kewajiban membayar utang lebih diutamakan dari pada membayar dividen (Widjaya \& Darmawan, 2018).

Besaran utang yang dimiliki perusahaan, akan mempengaruhi deviden yang akan dibagikan. Kas yang dipegang perusahaan dapat berasal dari utang, oleh karena itu makin besar utang akan menambah kelancaran operasional, investasi dan membayarkan deviden. Hasil penelitian ini sejalan dengan penelitian (Ginting, 2018) yang menyatakan bahwa leverage tidak berpengaruh secara signifikan terhadap kebijikan deviden. Namun tidak sejalan dengan penelitian Sari dan Sudjarni (2015) yang menyatakan bahwa leverage berpengaruh terhadap kebijakan deviden.

Hasil penelitian ini secara toritis mendukung teori sinyal akan tetapi secara statistic tidak signifikan pada alpha 5\% dan signifikan pada alpha $10 \%$. Dalam teori sinyal, hasil ini memberikan sinyal baik atau sinyal buruk kepada investor berupa informasi leverage dalam laporan keuangan. Pada tingkat tertentu, semakin tinggi leverage, semakin rendah dividen yang akan dibayarkan kepada pemegang saham. Dalam penelitian lebih lanjut, kebijakan dividen dikaitkan dengan nilai perusahaan (AlMalkawi et al.,2017 dan Anton, 2016).

Berdasarkan tabel diatas bahwa Likuiditas memiliki nilai T statistic sebesar 2,745 $<1.96$ dengan nilai koefisien sebesar 0.358 berarti Likuiditas berpengaruh terhadap kebijakan deviden dan signifikan pada 0.05 , yang artinya besar kecilnya likuiditas mempengaruhi kebijakan deviden.

Keterkaitan antara variabel likuiditas dengan kebijakan dividen mengkonfirmasi stakeholder theory yang mengasumsikan bahwa keberadaan perusahaan bukan merupakan entitas tunggal yang berdiri sendiri, akan tetapi juga berkaitan dengan pemangku kepentingan (stakeholder) baik internal maupun eksternal. Hal ini juga mengkonfirmasi signaling theory, dalam hal mana perusahaan yang memiliki likuiditas lebih baik mengindikaskan kemampuannya untuk membayarkan dividen.

Kuswanta, (2016) menyatakan bahwa likuiditas menunjukkan kemampuan suatu perusahan untuk memenuhi kewajiban keuangannya yang harus segera dipenuhi, atau kemampuan perusahaan untuk memenuhi kewajiban keuangan pada saat ditagih. Likuiditas berkaitan dengan kemampuan perusahaan untuk memenuhi kewajiban yang jatuh tempo baik kepada pihak internal perusahaan maupun pihak eksternal. Jika perusahaan memiliki kemampuan untuk melunasi kewajiban jangka pendeknya pada saat jatuh tempo maka perusahaan tersebut sebagai perusahaan yang likuid dan begitupun sebaliknya. Untuk dapat memenuhi kewajiban jangka pendeknya, perusahaan harus memiliki tingkat ketersediaan jumlah kas yang baik atau asset lancer lainnya yang juga dapat dengan segera dikonversi atau diubah menjadi kas. Posisi likuiditas perusahaan berpengaruh juga terhadap kemampuannya untuk melakukan pembayaran dividen. Dividen dibayarkan kepada pemegang saham dengan menggunkan kas dan tidak dengan laba ditahan. Untuk itu perusahaan harus memiliki kas yang cukup untuk melakukan pembayaran dividen. Semakin baik likuiditas perusahaan, semakin tinggi kemungknan perusahaan untuk membayarkan dividen kepada pemegang sahal. Hasil penelitian ini ini sejalan dengan penelitian Sari \& Sudjarni, (2015) yang menyatakan bahwa likuiditas berpengaruh terhadap kebijakan deviden. Namun tidak sejalan dengan penelitian Bilqis, (2018) yang menyatakan bahwa likuiditas tidak berpengaruh terhadap kebijakan deviden.

\section{KESIMPULAN}

Perusahaan makanan dan minuman tetep stabil walaupun dalam kondisi pandemic covid 19, dikarenakan perusahaan makanan dan minuman memiliki kontribusi besar untuk masyarakat luas. Penelitian ini fokus meneliti pengaruh leverage dan likuiditas terhadap kebijakan dividen, pada perusahaan yang bergerak dalam bidang makanan dan minuman periode 2016-2020. Berdasarkan hasil penelitian dan analisis data maka penelitian ini dapat ditarik kesimpulan sebagai berikui berikut dimana Leverage tidak berpengaruh terhadap Kebijakan Deviden dan Likuiditas berpengaruh positif dan signifikan terhadap Kebijakan Deviden.

Data yang dikumpulkan peneliti terbatas, sehingga diharapakan peneliti selanjutnya dapat mengembangkan pembaharuaan data dari penelitian sebelumnya dimana peneliti selanjutnya dapat menemukan variable-variable lain yang dapat mempengaruhi kebijkan deviden. Serta penelitian selajutnya dapat menggunakan sampel yang lebih luas lagi, tidak terbatas pada satu sub sektor sehingga hasil penelitian lebih representatif.

\section{REFERENSI}

Al-Malkawi, H.-A. nizar, Rafferty, M., \& Pillai, R. (2017). Dividend Policy: A Review of Literatures and Empirical Evidence. Singaporean Journal of Business Economics and Management Studies, 5(10), 38-45. https://doi.org/10.12816/0037572 
Ghozali, I. \& Latan, H. 2020. Partial Least Square : Konsep, Teknik dan Aplikasi SmartPLS 3.0. Semarang: Badan Penerbit Universitas Diponegoro.

Anton, S. G. (2016). The impact of dividend policy on firm value: A panel data analysis of Romanian listed firms. Journal of Public Administration, Finance and Law, 10(10), 107112. https://www.ceeol.com/search/articledetail id $=743810$

Bawamenewi, K., \& Afriyeni, A. (2019). Pengaruh Profitabilitas, Leverage, Dan Likuiditas Terhadap Kebijakan Dividen Pada Perusahaan Manufaktur Yang Terdaftar Di Bursa Efek Indonesia. Jurnal Pundi, 3(1), 27-40. https://doi.org/10.31575/jp.v3i1.141

Bilqis, H. (2018). Pengaruh investment opportunity set, likuiditas, profitabilitas, dan size (ukuran perusahaan) terhadap kebijakan dividen. http://repository.uinjkt.ac.id/dspace/handle/12 3456789/40270

Cahyani, N., \& Badjra, I. (2017). Pengaruh Leverage dan Likuiditas terhadap Kebijakan Dividen dengan Profitabilitas sebagai Variabel Intervening di Bei. E-Jurnal Manajemen Universitas Udayana, 6(10), 254591. https://ojs.unud.ac.id/index.php/Manajemen/ar ticle/view/31759/20952

Darmawan. (2018). Manajemen Keuangan: Memahami Kebijakan Dividen, Teori dan Praktiknya di Indonesia. Lembaga Penerbit UIN Sunan Kalijaga.

Deviyana, N. (2020, May 19). Pertumbuhan Industri Makanan Minuman Diprediksi Maksimal 5\% Medcom.id. Retrieved September 29, 2021, from medcom.id website: https://www.medcom.id/ekonomi/bisnis/5b2X oZ2K-pertumbuhan-industri-makananminuman-diprediksi-maksimal-5

Ginting, S. (2018). Pengaruh Likuiditas, Profitabilitas, dan Leverage terhadap Kebijakan Deviden pada Perusahaan LQ46 yang Terdaftar di Bursa Efek Indonesia Periode 2012-2016. Jwem Stie Mikroskil, 8(2), 195204.

https://www.mikroskil.ac.id/ejurnal/index.php/ jwem/article/view/564/277

Handayani, R. S., \& Rachadi, A. D. (2018). Pengaruh Ukuran Perusahaan Terhadap Manajemen Laba. Jurnal Bisnis Dan Akuntansi, 11(1), 33 56. https://doi.org/10.34208/jba.v11i1.109

Kasmir. (2008). Bank dan Lembaga Keuangan Lainnya. Jakarta: PT. Raja Grafindo Persada

Kasmir. (2012). Analisis Laporan Keuangan. Jakarta : PT. Raja Grafindo Persada.

Kurniawan, N., \& Mawardi, W. (2017). Analisis Pengaruh Profitabilitas Keputusan Investasi Keputusan Pendanaan dan Kebijakan Dividen terhadap Nilai Perusahaan. Diponegoro Journal of Management, 6(2), 1-11. https://ejournal3.undip.ac.id/index.php/djom/a rticle/view/17491

Kuswanta, T. (2016). Pengaruh Leverage, Profitabilitas, dan Ukuran Perusahaan yang Terdaftar di Indeks Kompas 100. Jurnal Ilmu Manajemen, $\quad$ 13(2), 162-174. https://journal.uny.ac.id/index.php/jim/rt/meta data/25528/0

Market Bisnis Indonesia. (2020, November 28). Penjualan Turun, Sentra Food Indonesia (FOOD) Berbalik Merugi. https://market.bisnis.com/read/20201128/192/ 1323666/penjualan-turun-sentra-foodindonesia-food-berbalik-merugi

Patiruhu, J. R., \& Paais, M. (2020). Effect of Liquidity, Profitability, Leverage, and Firm Size on Dividend Policy. Journal of Asian Finance, Economics and Business, 7(10), 3542.

https://doi.org/10.13106/jafeb.2020.vol7.no10. 035

Prasetyanta, A. (2016). Pengaruh Perubahan Dividen Terhadap Profitabilitas Perusahaan Pada Masa Yang Aakan Datang (Future Profitability). Jurnal Ekonomi Dan Bisnis, 17(2), 129. https://doi.org/10.24914/jeb.v17i2.278.

Prawira Ismanwan Yudi, Moh. Dzulkiron AR, M. G. W. E. N. (2014). Pengaruh, Leverage, Likuiditas, Profitabilitas Dan Ukuran Perusahaan Terhadap Kebijakan Dividen (Studi pada Perusahaan Perbankan yang Terdaftar di Bursa Efek Indonesia Tahun 2010-2013 ). Jurnal Administrasi Bisnis S1 Universitas Brawijaya, 15(1), 1-7. http://administrasibisnis.studentjournal.ub.ac.i d/index.php/jab/article/view/608

Ramachandran, R. (2020). Theories of Stakeholder Management. SSRN Electronic Journal, January 2019. https://doi.org/10.2139/ssrn.3535087

Samrotun, Y. C. (2015). kebijakan dividen pada perusahaan Industri Barang Konsumsi yang terdaftar di Bursa Efek Indonesia ( BEI ) selama periode tahun 2011-2014 .. Jurnal Paradigma, 13(01), 92-103. https://media.neliti.com/media/publications/11 6095-ID-kebijakan-dividen-dan-faktor-faktoryang.pdf

Novita Sari, K., \& Sudjarni, L. (2015). Pengaruh Likuiditas, Leverage, Pertumbuhan Perusahaan, Dan Profitabilitas Terhadap Kebijakan Dividen Pada Perusahaan Manufaktur Di Bei. E-Jurnal Manajemen Universitas Udayana, 4(10), 255134. https://www.neliti.com/publications/255134/p engaruh-likuiditas-leverage-pertumbuhanperusahaan-dan-profitabilitas-terhadap

Simetris, S. A., \& Darmawan, A. (2019). Pengaruh Diversifikasi, Leverage, Dan Profitabilitas Terhadap Nilai Perusahaan (Studi pada 
Perusahaan Industri Barang Konsumsi Yang Terdaftar Di Bursa Efek Indonesia Tahun 20132017). Jurnal Administrasi Bisnis (JAB), 74(1), 39-47.

http://administrasibisnis.studentjournal.ub.ac.i d/index.php/jab/article/view/2943

Sudiani, N., \& Darmayanti, N. (2016). Pengaruh Profitabilitas, Likuiditas, Pertumbuhan, Dan Investment Opportunity Set Terhadap Nilai Perusahaan. E-Journal Manajemen Universitas Udayana, 5(7), 245861. https://ojs.unud.ac.id/index.php/Manajemen/ar ticle/view/20349

Sugiyono, (2011). Metode Penelitian Kuantitaif Kualitatif dan $R \&$ \& Bandung: Alfabeta

Sugiyono, (2017). Metode Penelitian Pendidikan :(pendekatan kuantitatif, kualitatif dan $R \& D)$.

Tahu, G. P., \& Susilo, D. D. B. (2017). Effect of Liquidity, Leverage and Profitability to The Firm Value (Dividend Policy as Moderating Variable) in Manufacturing Company of Indonesia Stock Exchange. Research Journal of Finance and Accounting, 8(18), 89-98. https://core.ac.uk/download/pdf/234632117.pd $\mathrm{f}$

Trisna, I. K. E. R., \& Gayatri, G. (2019). Ukuran Perusahaan Memoderasi Pengaruh Free Cash Flow dan Leverage Terhadap Kebijakan Dividen. E-Jurnal Akuntansi, 26, 484. https://doi.org/10.24843/eja.2019.v26.i01.p18

Widiyanto, M.A. (2013). Statistika Terapan, Konsep dan Aplikasi SPSS/Lisrel dalam Penelitian Pendidikan, Psikologi dan Ilmu Sosial Lainya.Jakarta : PT Elex Media Komputindo.

Widjaya, N. U., \& Darmawan, A. (2018). Pengaruh Free Cash Flow , Kepemilikan Saham Manajer , Kepemilikan Saham Institusi, dan Leverage terhadap Dividen (Studi pada Perusahaan Sub Sektor Farmasi di Bursa Efek Indonesia (BEI). Jurnal Administrasi Bisnis (JAB), 64(1), 10-18. http://administrasibisnis.studentjournal.ub.ac.i d/index.php/jab/article/view/2720

Zuhroh, I. (2019). The Effects of Liquidity, Firm Size, and Profitability on the Firm Value with Mediating Leverage. KnE Social Sciences, 3(13), https://doi.org/10.18502/kss.v3i13.4206. 